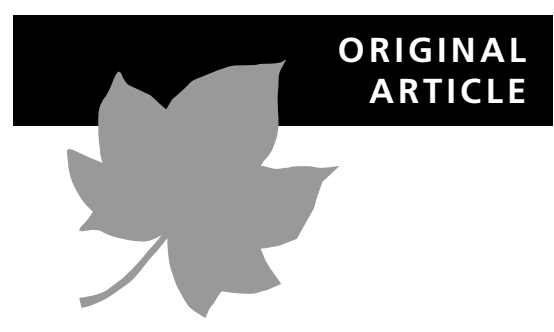

\section{Biogeographical revision of Argentina (Andean and Neotropical Regions): an analysis using freshwater fishes}

\author{
Hugo L. López ${ }^{1 \star}$, Roberto C. Menni ${ }^{2}$, Mariano Donato ${ }^{3}$ and \\ Amalia M. Miquelarena ${ }^{2}$
}

${ }^{1}$ División Zoología Vertebrados, Museo de la Plata and Comisión de Investigaciones Científicas, Buenos Aires, ${ }^{2}$ Consejo Nacional de Investigaciones Científicas y Técnicas and División Zoología Vertebrados, Museo de la Plata, La Plata and ${ }^{3}$ Laboratorio de Sistemática y Biología Evolutiva (LASBE), Museo de la Plata - CONICET, Museo de La Plata, La Plata, Argentina

${ }^{*}$ Correspondence: Hugo L. López, División Zoología Vertebrados, Museo de La Plata, Paseo del Bosque s/n, 1900, La Plata, Argentina. E-mail: hlopez@fcnym.unlp.edu.ar

\section{ABSTRACT}

Aim To provide an objective geographic framework displaying the distribution patterns of freshwater fishes from Argentina.

Location Argentina, southern South America.

Methods Parsimony analysis of endemicity (PAE) and similarity and cluster analyses were applied to presence and absence data on 440 fish species from 52 localities in Argentina. Both 50\% majority consensus and strict consensus analyses were undertaken in the first case, and the Jaccard similarity index was used in the second.

Results Five ichthyogeographic provinces are described based on a PAE of the 52 localities. A cluster analysis provided similar results.

Main conclusions The following zoogeographic provinces are proposed for Argentine freshwater fish fauna following the International Code of Area Nomenclature: Andean Cuyan, Patagonian, Aymaran, Great Rivers and Pampean. The former two are placed within the Andean Subregion of the Austral Region, and the latter three within the Neotropical Subregion of the Holotropical Region. These provinces, based on results coinciding with PAE and cluster analysis, represent the first classification of Argentine provinces based on objective methods. Some small regions of endemism and some localities remain separated from the proposed regions. The new scheme includes valuable empirical information from previous schemes, and is in agreement with ecological zones and other environmental arrangements proposed earlier.

\section{Keywords}

Areas of endemism, Argentina, biogeography, freshwater fishes, ichthyogeographic provinces, limnology, Neotropics, PAE.

\section{INTRODUCTION}

Probably the greatest change in the zoogeography of South America was the division of the Neotropical Region into a north-eastern area, which retained the original name, and a south-western area, the Andean Region, belonging to the Holotropical and Austral kingdoms, respectively (Amorim \& Tozoni, 1994; Morrone, 1996, 2002; Humphries \& Parenti, 1999). Following the work of Eigenmann (1909), Ringuelet (1961, 1975) treated in considerable detail the distribution of fishes in South America, explicitly considering the relationship between the western part of Argentina and areas located in New Guinea and Australia.
There are numerous classifications for the distribution of the freshwater fishes of Argentina (see Table 1), as well as other wider biogeographical classifications of South America (see Crisci et al., 1991a, b; Humphries \& Parenti, 1999; Morrone, 2006). The majority of these classifications tend to be in agreement (Menni, 2004). However, the most popular system, that proposed by Ringuelet (1975), was challenged by Arratia et al. (1983), who considered that the AndeanCuyan Province had stronger affinities with the Patagonian Province than with the Paranensean Province. Furthermore, Arratia et al. (1983) extended the western limit of the Paranensean fauna to the eastern slope of the Andes. These modifications of Arratia et al. (1983) coincide with an earlier 
Table 1 Zoogeographic studies referring to Argentine fishes.

\begin{tabular}{|c|c|}
\hline Eigenmann (1909) & Mainly fishes from Patagonia \\
\hline Lahille (1929) & $\begin{array}{l}\text { Silversides, Argentine and } \\
\text { Chilean geography }\end{array}$ \\
\hline Mac Donagh $(1934,1938)$ & Geography of Argentinean fishes \\
\hline Pozzi (1945) & Main ichthyogeographic regions \\
\hline Ringuelet et al. (1967) & Fishes from Argentina \\
\hline Géry (1969) & Ichthyogeography of South America \\
\hline McDowall (1971a,b) & Distribution of galaxiids \\
\hline Ringuelet (1975) & $\begin{array}{l}\text { Geography and ecology of } \\
\text { Argentinean fishes }\end{array}$ \\
\hline Cabrera \& Willink (1973) & $\begin{array}{l}\text { Biogeography of Latin America } \\
\text { including fish examples }\end{array}$ \\
\hline Del Castillo (1986) & $\begin{array}{l}\text { Numerical taxonomy applied } \\
\text { to fish families distribution }\end{array}$ \\
\hline Berra (2001) & $\begin{array}{l}\text { Distribution of world } \\
\text { freshwater fishes }\end{array}$ \\
\hline Arratia et al. (1983) & $\begin{array}{l}\text { Geography and ecology } \\
\text { of Argentinean fishes }\end{array}$ \\
\hline Vari $(1988,1991,1992)$ & Biogeography of curimatid fishes \\
\hline Schaefer $(1991,1997)$ & Biogeography of Hypoptopomatinae \\
\hline Banarescu (1995) & Biogeography of fresh waters \\
\hline Menni \& Gómez (1995) & Disjunction and gradients \\
\hline Menni et al. (1996) & Ecological patterns \\
\hline Bonetto (1998) & Fishes from the Rio de la Plata basin \\
\hline Almirón et al. (1997) & $\begin{array}{l}\text { Border between subregions } \\
\text { in Argentina }\end{array}$ \\
\hline Arratia (1997) & Brazilian and Austral fishes \\
\hline Dyer $(1998,2000)$ & Silversides geography \\
\hline Malabarba et al. (1998) & Collected papers \\
\hline Matthews (1998) & Global distribution of freshwater fishes \\
\hline Morrone (2001) & $\begin{array}{l}\text { Biogeography of Latin America } \\
\text { and the Caribbean }\end{array}$ \\
\hline Sivasundar et al. (2001) & $\begin{array}{l}\text { Population and distribution } \\
\text { of Prochilodus }\end{array}$ \\
\hline López et al. (2002) & Ecoregions of Argentina \\
\hline Baigún \& Ferriz (2003) & Fishes of Patagonia \\
\hline Cussac et al. (2004) & Distribution of galaxiids \\
\hline Menni (2004) & Fishes \& environments in Argentina \\
\hline $\begin{array}{l}\text { López \& Miquelarena } \\
(2005)\end{array}$ & $\begin{array}{l}\text { Genera shared by Argentina } \\
\text { and nearby countries }\end{array}$ \\
\hline Menni et al. (2005) & Gradients in northwestern Argentina \\
\hline Hubert \& Renno (2006) & $\begin{array}{l}\text { Biogeography of northern } \\
\text { South America }\end{array}$ \\
\hline Ruzzante et al. (2006) & Phylogeography of Percichthys \\
\hline
\end{tabular}

classification of Ringuelet (1961) for the entire Argentinean fauna.

In recent years there has been a sudden increase in the number of species descriptions of fishes in the Argentine territory. Important examples are the genus Astyanax within the characiforms (Miquelarena \& Menni, 2005) and further discoveries in the north-eastern and north-western regions of the country. According to the recent survey by López \& Miquelarena (2005), the freshwater fishes of Argentina are assigned to 183 genera comprising 438 described species. The latter number is a $398 \%$ increase over the number given by Géry (1969). Furthermore, several recent papers focusing on particular taxa and areas provide a much more accurate description of the geographic distribution of fishes than was previously available (for example Almirón et al., 1992; Haro \& Bistoni, 1996; del Barco, 1997; Haro et al., 1998; Sverlij et al., 1998; López et al., 2001, 2003, 2005; Baigún \& Ferriz, 2003; Monasterio de Gonzo, 2003; Cussac et al., 2004; Menni, 2004; Butí \& Cancino, 2005; Casciotta et al., 2005; Liotta, 2005; López \& Miquelarena, 2005; Menni et al., 2005; Monasterio de Gonzo et al., 2005).

Over the last 25 years, several research groups have worked on fish systematics, ecology and distribution, with extensive field work being carried out in many areas of Argentina. Their results have provided a large number of new records and new species, and in many cases communities and limnology were also studied. The information derived from these activities is summarized below.

1. Improvement in the knowledge of the fish fauna of central Argentina (Menni et al., 1984; Casciotta et al., 1989; Miquelarena et al., 1990; Miquelarena \& Menni, 1992; Ferriz, 1996; Haro \& Bistoni, 1996).

2. Changes in the composition of the fish fauna of the Lagunas Encadenadas del Oeste, where richness increased to 18 species from 14 previously known (Miquelarena \& López, 1995).

3. New information on the north-western region, which shows differences from pampasic assemblages fishes (Miquelarena \& Aquino, 1995; Butí, 1999; Fernández \& Schaefer, 2003; Fernández \& Vari, 2004; Fernández \& de Pinna, 2005; Menni et al., 2005; Miquelarena \& Menni, 2005).

4. The presence of several genera shared between Bolivia and Argentina, supporting the north-western assemblage (López \& Miquelarena, 2005; Menni et al., 2005).

5. The faunal composition of many aquatic environments within the flood plains of the Paraguay River in north-eastern Argentina (Menni et al., 1992).

6. A high rate of description of new species, many of which are apparently endemics, in north-eastern Argentina (López et al., 2005).

7. New information on Argentine Mesopotamian fishes (López et al., 2005), particularly in the Iberá swamps (Casciotta et al., 2005).

We used the above-mentioned information to find geographical patterns among a large number of aquatic environments throughout southern South America. Based on this we propose a new zoogeographical classification for freshwater fishes from the Argentine territory.

\section{MATERIALS AND METHODS}

We analysed a total of 52 localities in Argentina, for which we obtained information on the composition of the fish fauna from the literature and from our own data. These localities were basins, individual streams and small water courses, and lentic environments. For each locality we assessed the presence or absence of 440 reported species, resulting in an absence/ presence binary matrix of 440 species in 52 localities. The matrix is included in Appendix S1 (see Supplementary Material). 
Numbers of localities in clades correspond to numbers in Fig. 4; Jenynsia multidentata, Cnesterodon decemmaculatus and Odontesthes bonariensis were excluded from the analysis because their distributions have been modified by aquaculture and other human activities.

In order to uncover potential biogeographical patterns, we examined the data using two techniques, namely parsimony analysis of endemicity (PAE) and multivariate (cluster) analysis.

\section{Parsimony analysis of endemicity (PAE)}

Parsimony analysis of endemicity is a method that aims to find similarities between areas based on natural patterns of distribution. PAE classifies localities, areas, or quadrats according to their shared taxa by means of a parsimony algorithm (see Rosen, 1988). The result is a hierarchical classification of the geographical units (Crisci et al., 2000, 2003). For this purpose, we analysed the binary data matrix with PaUp (Swofford, 1998) using a heuristic search with 1000 random addition sequences.

Branch support is based on a bootstrap analysis (Felsenstein, 1985) and a decay analysis (Bremer, 1988), the former computed with PAUP and the latter performed by constructing a PAUP-command file in MacClade (Maddison \& Maddison, 2001) and then performing a calculation in PAUP. In order to characterize the areas, the synapomorphies (= endemic species) for each area (= clade) were used. Non-endemic but very common species present in basins, streams or lentic habitats were considered in the descriptions of areas.

\section{Multivariate analysis}

Multivariate methods can be regarded as an alternative to PAE for classifying biotas. Assemblages can be identified subjectively by assessing how far the biota in one area corresponds to that in another, and thereby grouping areas accordingly. Some assemblages are closer in taxonomic composition, which can be expressed statistically in terms of cluster hierarchies or relative biotic distances. The resulting patterns are expressed in numerous ways, cluster diagrams being the most common (Rosen, 1988).

In order to perform the cluster analysis, we used the Jaccard association index to construct the similarity matrix (Hubalek, 1982; Murguía \& Villaseñor, 2003) and UPGMA (unweighted pair-group method using arithmetic averages) was applied to obtain the clustering graph (dendrogram). Cluster analysis was performed using the program PAST (Hammer et al., 2001). We also computed the co-phenetic coefficient (Sokal \& Rohlf, 1962) to evaluate the degree of distortion of the analysis.

In order to compare groups between methods, we labelled clades with Roman numerals and clusters with capital letters and Arabic numbers (see below). The biogeographical classification obtained in this paper follows the International Code of Area Nomenclature (ICAN) (Ebach et al., 2007).

\section{RESULTS}

\section{Parsimony analysis of endemicity}

Parsimony analysis of endemicity yielded 1196 trees with length (L) 1045 (consistency index $(\mathrm{CI})=34$; retention index $(\mathrm{RI})=61)$. All of the most parsimonious trees were retained, but we present only the strict consensus and the majorityrule trees. The strict consensus tree and support statistics are shown in Fig. 1. Bootstrap values were moderate to high, with eight branches supported by more than 50\%. Decay indexes were low, maximally equal to one.

The five main clades of localities can be identified in the strict consensus tree. One clade is formed by the Middle and Lower Paraná River, the Upper Paraná River, the Uruguay River, the Río de la Plata and its tributaries, the Paraná River Delta, the Bermejo River, the Pilcomayo River, the Formosean swamp zone, the Santa Fé swamp zone, and the Lower Paraguay River. A smaller clade contains the tributaries of the Paraná River in Misiones and the Iguazú River. The former clade presented a moderate bootstrap support value (64\%), and the latter a high bootstrap support value (99\%). A third clade contains the Chubut-Senguer, the Negro, Chico and Santa Cruz, and Deseado rivers, with a low bootstrap support value $(<50 \%)$. A fourth clade is formed by the tributaries of the Chilecito Valley, Abaucán-Salado River, tributaries of the Salar de Pipanaco, and Del Valle River and its tributaries, and rivers and creeks of the eastern slope of Mount Ambato. The fifth clade includes the Salí-Dulce and Juramento rivers in Salta, the Tercero, Cuarto and Carcarañá rivers in central Argentina, the Salado-Vallimanca, Segundo and Primero rivers, the Pampean basins of the Atlantic slope and the Southwestern Pampean basins, the Northwestern Córdoba rivers, and the Quinto and Chorrillos rivers. These last two clades have a very low decay index. The remaining localities are unresolved.

The 50\% majority-rule consensus (Fig. 2) included, in Clade IV, several localities that were unresolved in the strict consensus. This clade is formed by the tributaries of the Llancanelo (brackish) lagoon and the Atuel, Diamante, San Juan, Jachal, Vinchina, Tunuyán, Desaguadero, Colorado, and Mendoza rivers, and has a high frequency of bipartitions. The clade of the strict consensus tree comprising the Chubut, Negro, Chico and Santa Cruz, and Deseado rivers is included in a major clade together with the Coyle, Gallegos and Chico del Sur rivers, the rivers and creeks from Tierra del Fuego, environments in the Malvinas Islands, and Isla de los Estados (Clade V). This clade shows a high frequency of bipartitions. Two clades of the strict consensus tree (Fig. 1) are grouped in a major clade together with the Dorado and del Valle rivers in Salta, showing $75 \%$ of bipartitions (= frequency of occurrence) (Clade I). Five localities are unresolved and will be discussed below. Endemic species for each area are shown in Table 2, and species supporting clades are shown in Table 3.

The detailed composition of clades resulting from the 50\% majority consensus tree is as follows. 
Figure 1 Strict consensus tree of 1196 trees $(\mathrm{L}=1045 ; \mathrm{CI}=34$; $\mathrm{RI}=61)$ obtained from parsimony analysis of endemicity (PAE). Bootstrap values are shown above the branches with values $>50 \%$; decay index values are shown below the branches with values $>0$.

\section{Clade I}

31. Middle and Lower Paraná River

30. Upper Paraná River

34. Uruguay River

33. Rio de la Plata and its tributaries

32. Paraná River delta

38. Bermejo River

37. Pilcomayo River

35. Formosean swamp zone

36. Santa Fé Province swamp zone

39. Lower Paraguay River

40. Iguazú River

41. Tributaries of the Paraná River in Misiones

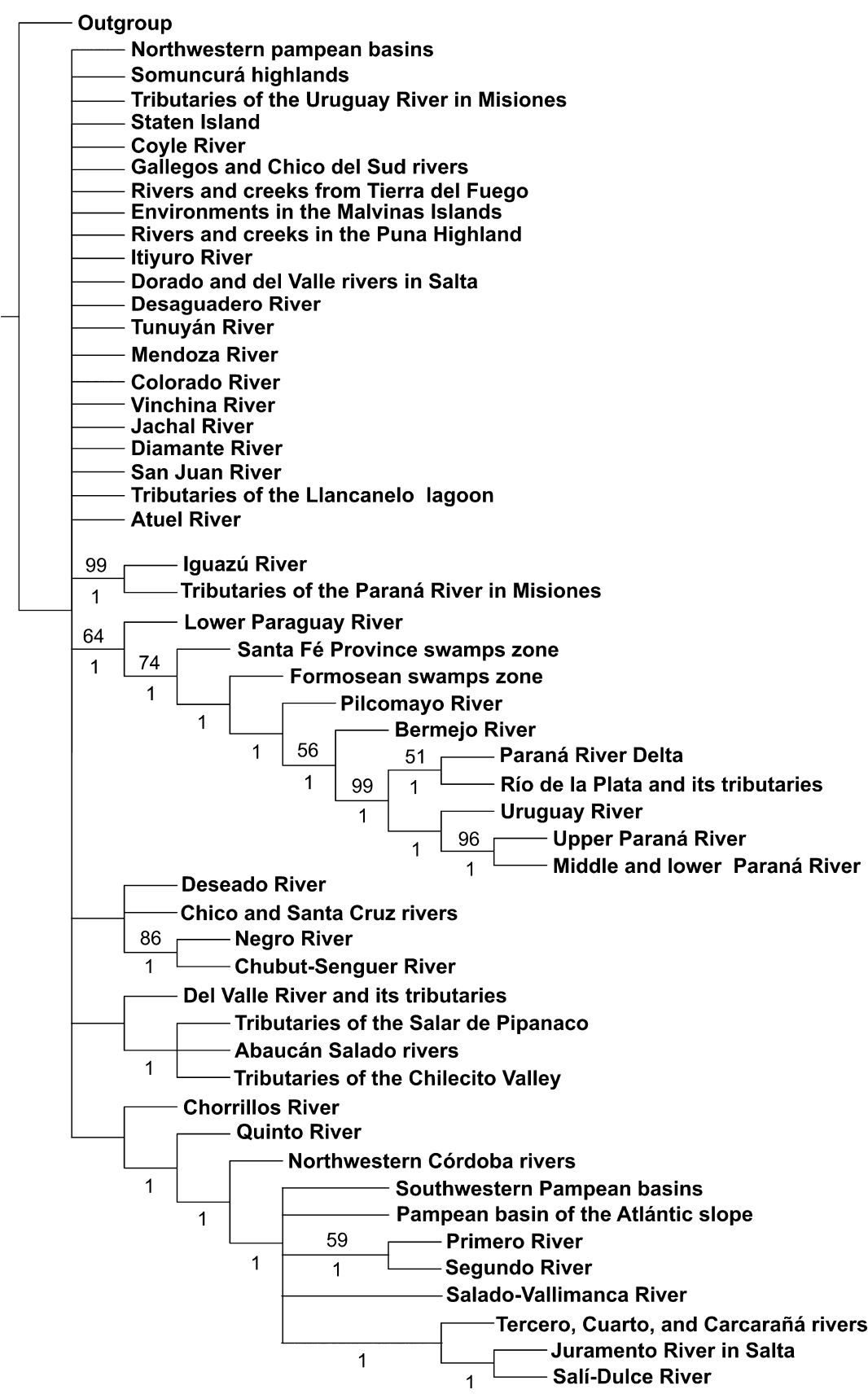

51. Dorado and Del Valle rivers in Salta

All these environments belong to the Río de la Plata basin, and are part of the Subtropical Potamic Axis (López et al., 2002). The expansion of the Paranensean fauna in all these environments have been extensively discussed and demonstrated previously (Ringuelet, 1975; Vari, 1988; Schaefer, 1997; Menni, 2004).

Clade II

46. Salí-Dulce River

50. Juramento River in Salta

45. Tercero, Cuarto and Carcarañá rivers

47. Salado-Vallimanca River 


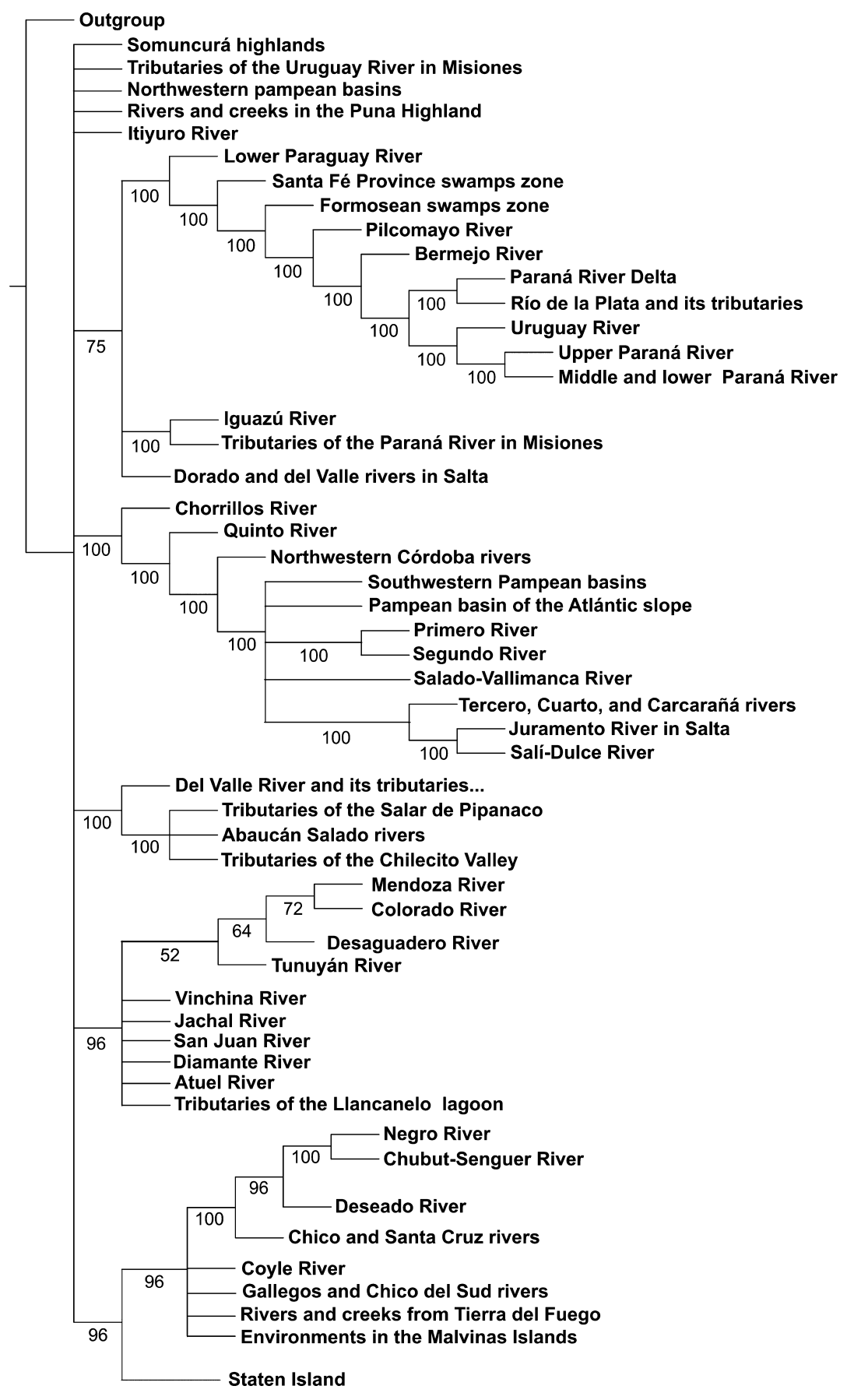

Figure 2 50\% majority-rule consensus tree of 1196 trees $(\mathrm{L}=1045 ; \mathrm{CI}=34$; $\mathrm{RI}=61)$ obtained from parsimony analysis of endemicity (PAE). Frequencies of occurrence are shown above the branches.
44. Segundo River
43. Primero River
49. Pampean basin of the Atlantic slope
48. South-western Pampean basins
42. North-western Córdoba rivers
28. Quinto River
27. Chorrillos River

This clade somewhat exceeds the area usually attributed to the Pampasic fishes. This name is usually applied to taxa inhabiting the typical 'lagunas' (lakes of third order) and rivers from the wet Pampa (Pampasia Bonaerense, in the sense of
Ringuelet, 1975). In a strict geological sense, the Pampean Zone reaches up to the Pampean Highland (Frenguelli, 1946; Tonni \& Cione, 1997). This clade grouped the most important rivers in central Argentina, of which the Tercero, Cuarto, Carcarañá and Juramento are connected with the Paraná River at present, whereas the Primero, Segundo and Salí-Dulce were connected with the Paraná River in the past. There are other endorrheic basins, such as the Quinto and Chorrillos rivers. The Pampean basin of the Atlantic slope includes small creeks that flow into the Atlantic Ocean and others that disappear into coastal sand dunes. 
Table 2 List of endemic species corresponding to each of the proposed zoogeographic provinces.

\section{Clade III}

23. Tributaries of the Salar de Pipanaco

24. Abaucán-Salado River

25. Tributaries of the Chilecito Valley

26. Del Valle River and its tributaries, rivers and creeks of the eastern slope of Mount Ambato.

These localities are all endorrheic basins in the provinces of Catamarca and La Rioja, within a mostly desert landscape.

\section{Clade IV}

6. Mendoza River

9. Colorado River

8. Desaguadero River

7. Tunuyán River
Andeancuyan Patagonian Aymaran Pampean Great Rivers

\begin{tabular}{llll}
\hline Olivaichthys cuyanus & $\mathrm{X}$ & & \\
Silvinichthys mendozensis & $\mathrm{X}$ & & \\
Trichomycterus heterodontus & $\mathrm{X}$ & & \\
Olivaichthys mesembrinus & & $\mathrm{X}$ & \\
Rhamdella aymarae & & $\mathrm{X}$ & \\
Trichomycterus belensis & & $\mathrm{X}$ & \\
Bryconamericus eigenmanni & & $\mathrm{X}$ \\
Astyanax cordovae & & $\mathrm{X}$ \\
Austrolebias robustus & & $\mathrm{X}$ \\
Astyanax hermosus & & $\mathrm{X}$ \\
Characidium borellii & & $\mathrm{X}$ \\
Silvinichthys bortayro & & $\mathrm{X}$
\end{tabular}

Pimelodus argenteus

Megalonema argentina

Apteronotus ellisi

Xyliphius barbatus

Pimelodus absconditus

Rhamphichthys hahni

Hyphessobrycon wajat

Xyliphius lombarderoi

Corydoras carlae

Brochiloricaria chauliodon

Hemmigramus mattei

Hyphessobrycon igneus

Pimelodus brevis

Bryconamericus uporas

Loricariichthys edentatus

Astyanax latens

Tridentopsis cahuali

Astyanax leonidas

Astyanax ita

Bryconamericus ika

Astyanax troya

Astyanax tupi

Bryconamericus agna

Bryconamericus mennii

Bryconamericus sylvicola

Gymnogeophagus che

Oligosarcus menezesi
$\mathrm{X}$
$\mathrm{X}$
$\mathrm{X}$
$\mathrm{X}$
$\mathrm{X}$
$\mathrm{X}$

$\mathrm{X}$

$\mathrm{X}$

$\mathrm{X}$

$\mathrm{X}$

$\mathrm{X}$

$\mathrm{X}$

$\mathrm{X}$

$\mathrm{X}$

$\mathrm{X}$

$\mathrm{X}$

$\mathrm{X}$

$\mathrm{X}$

$\mathrm{X}$

$\mathrm{X}$

$\mathrm{X}$

$\mathrm{X}$

$\mathrm{X}$

$\mathrm{X}$

$\mathrm{X}$

$\mathrm{X}$

$\mathrm{X}$

$\mathrm{X}$

$\mathrm{X}$

$\mathrm{X}$

X

$\mathrm{X}$

$\mathrm{X}$
1. Vinchina River

3. Jachal River

5. San Juan River

2. Diamante River

4. Atuel River

10. Tributaries of the Llancanelo brackish lagoon

These are environments of north-western Argentina between $28^{\circ} 30^{\prime} \mathrm{S}$ and $35^{\circ} 20^{\prime} \mathrm{S}$ and centred about 68-69 W. Trichomycterus heterodontus and Hatcheria macraei have been reported from the Vinchina River, an endorrheic course in La Rioja province (Arratia et al., 1983; López et al., 2002; Menni, 2004). The rest of the rivers in the list are tributaries of the Desaguadero River, which collects most rivers of the area. Originally, and in some periods during the present, the Desaguadero River flowed into the Colorado River (Mazza, 1961). 


\section{H. L. López et al.}

Table 3 List of species supporting clades (see Fig. 2).

\begin{tabular}{ll}
\hline Clades & Synapomorphies \\
\hline
\end{tabular}

(Upper Paraná River, Middle and Lower Paraná River)

(Río de la Plata, Paraná River Delta)

(Uruguay River, (Upper Paraná River, Middle and Lower Paraná River))

(Uruguay River, Upper Paraná River, Middle and Lower Paraná River, Río de la Plata, Paraná River Delta)

(Bermejo River, Uruguay River, Upper Paraná River, Middle and Lower Paraná River, Río de la Plata, Paraná River Delta)

(Pilcomayo River, Bermejo River, Uruguay River, Upper Paraná River, Middle and Lower Paraná River, Río de la Plata, Paraná River Delta)

(Formosean swamps zone, Pilcomayo River, Bermejo River, Uruguay River, Upper Paraná River, Middle and Lower Paraná River, Río de la Plata, Paraná River Delta)

(Santa Fe swamps zone, Formosean swamps zone, Pilcomayo River, Bermejo River, Uruguay River, Upper Paraná River, Middle and Lower Paraná River, Río de la Plata, Paraná River Delta) (Iguazú River, Tributaries of the Paraná River in Misiones)

(Primero River, Segundo River)

(Negro River, Chubut-Senguer River, Deseado River, Chico and

Santa Cruz Rivers, Coyle River, Rivers and creeks from

Tierra del Fuego, Gallegos and

Chico del Sur Rivers, Environments in the Malvinas Islands)

(Negro River, Chubut-Senguer River, Deseado River, Chico

and Santa Cruz Rivers, Coyle River, Rivers and creeks from

Tierra del Fuego, Gallegos and Chico del Sur Rivers, Environments

in the Malvinas Islands, Staten Island
Hyphessobrycon auca; Hyphessobrycon elachys; Hyphessobrycon eques; Hypophthalmus oremaculatus; Hypostomus meleagris; Ituglanis eichorniarum; Laetacara dorsigera; Leporinus elongatus; Metynnis mola; Potamorrhaphis eigenmanni; Pterolebias bokermanni; Rineloricaria lanceolata

Phalloptychus januarius; Pimelodus brevis; Rhamdella jenynsii Apistogramma trifasciata; Hypostomus alatus; Hypostomus luteomaculatus; Rhamphychthys hahni; Paraloricaria agastor Ageneiousus inermis; Ramnogaster melanostoma; Rhinelepis strigosa; Schizodon platae

Megalonema platanum; Oxydoras kneri; Potamotrygon brachyura; Raphiodon vulpinus

Pterodoras granulosus

Bergiaria westermanni

Odontostilbe pequira; Sorubim lima; Triportheus nematurus

Astyanax leonidas; Crenicichla gaucho; Hypostomus derbyi; Hypostomus myersi; Imparfinis hollandi; Trichomycterus davisi Astyanax cordovae

Galaxias plate

Galaxias maculatus

\section{Clade V}

\section{Negro River}

13. Chubut-Senguer River

14. Deseado River

15. Chico and Santa Cruz rivers

16. Coyle River

18. Gallegos and Chico del Sur rivers

17. Rivers and creeks from Tierra del Fuego

19. Environments in the Malvinas Islands

20. Isla de los Estados.

All of these are Patagonian rivers in a strict geographic sense. The Colorado River, although geographically usually considered the northern border of Patagonia, is included in Clade IV.

\section{Unresolved localities}

The north-western Pampean basins, Somuncurá highlands, the tributaries of the Uruguay River in Misiones, the rivers and creeks in the Puna Highlands, and the Itiyuro River resulted in a basal polytomy in the PAE and were not included in any of our provinces.
North-western Pampean basins (29): These basins include lakes and ponds, with a relatively high salinity and long desiccation periods. They have a small fish fauna composed of Cheirodon interruptus, Austrolebias nonoiuliensis and Rhamdia quelen. In this area, Pampean assemblages are clearly recognizable in completely new communities that developed following an increase in rainfall and temperature in areas that were dry half a century ago (Gómez et al., 2004; Gómez \& Menni, 2005).

Somuncurá Highlands (12): The Somuncurá plateau is a peculiar environment in the centre of northern Patagonia, with small streams inhabited by a few species. The endemic characid Gymnocharacinus bergi, apparently related to Bryconamericus (Géry, 1978; Miquelarena et al., 2005), lives in the Valcheta creek. This creek is fed by thermal springs that maintain a high water temperature suitable for G. bergi (Menni \& Gómez, 1995). This species has been separated from the rest of the subtropical fauna at least since the desertification of the Pampean region in Miocene times (Vucetich \& Verzi, 1999; Ortiz-Jaureguizar \& Cladera, 2006).

Jenynsia multidentata has been reported from the Valcheta Creek, the Paja Alta Creek and the Curicó pond, and 
Cnesterodon decemmaculatus from the Curicó pond only. Oncorrhynchus mykiss and Salvelinus fontinalis have been introduced in several places in the basin (Ortubay et al., 1997), but high temperatures exclude them from the area where G. bergi lives.

The degree of endemism in the highlands is also high for other groups, especially amphibians and reptiles among the vertebrates (Cei, 1969). Considering the possible relationships of G. bergi with other characiform subfamilies, this area is certainly an enclave of the Great Rivers Province.

Tributaries of the Uruguay River in Misiones and nearby localities (52): The most north-eastern section of Argentina in the state of Misiones is a particularly complex area (Roig \& Cei, 1961; Cabrera \& Willink, 1973; López et al., 2002). It has been considered part of the Alto Paraná Province (Ringuelet, 1975; Vari, 1988). In recent times this area has been the richest source of new species, most of them still endemic to isolated small basins. New species include Astyanax ojiara, Astyanax saguazu, Astyanax paris, Bryconamericus ytu, Rineloricaria missioneira, Hypobrycon poi and Australoheros tembe. Some species initially described as endemics were later found in nearby countries (Miquelarena \& Menni, 2005). In the cluster analysis, the tributaries of the Uruguay River in Misiones appear to be related to the Cluster C fauna, at a low level of similarity.

Itiyuro River (21): This river, with sources in Bolivia, belongs to an endorrheic basin, but may reach the Bermejo River during the heaviest floods. Its ichthyofauna, recently described (Menni et al., 2005), includes several species with clear Paranensean relationships, although Trichomycterus barbouri and the endemic Rhamdella aymarae are not among these.

Rivers and creeks in the Puna Highland (22): These are water courses of the rithron type, mainly under strong physical conditions in dry highlands. Five species were considered in the matrix, including Bryconamericus thomasi and Jenynsia maculata, which have rather restricted distributions in northwestern Argentina, and Trichomycterus belensis, which occurs only in a tributary creek of the Laguna Blanca in Catamarca.

\section{Multivariate analysis}

The dendrogram (Fig. 3) derived from the application of the Jaccard index presents five groups (A1, A2, B, C1 and C2). Cluster $\mathrm{C} 1$ groups the localities defined in the majority-rule consensus cladogram as Clade I, with the exception of the Dorado and del Valle rivers in Salta. This cluster is related to Cluster C2. Cluster C2 includes the localities defined in the strict and 50\% majority-rule consensus cladograms as Clade II, except for the inclusion of the Dorado and Del Valle rivers in Salta and the exclusion of the Chorrillos and Quinto rivers, which are in Cluster B.

Cluster A1 includes the same localities as Clade IV, and Cluster A2 includes the same localities as Clade V of the $50 \%$ majority-rule consensus cladogram. Cluster B, however, corresponds to Clade III, but does not include the Itiyuro River, rivers and creeks in the Puna Highland, far to the north, or the
Chorrillos and Quinto rivers and the north-western Pampean basins.

Clusters B, C1 and C2 appear to be related and are separate from clusters A1 and A2, which form another main cluster. These relationships among groups are the same as those proposed by Arratia et al. (1983).

The five unresolved localities of the PAE clustered as follows: the tributaries of the Uruguay River in Misiones are related to the Great Rivers and Pampean provinces (Cluster C) at a very low level, and the Somuncurá Plateau joins the other clusters at the lowest level of similarity. The north-western Pampean basins, the rivers and creeks in the Puna Highland, and the Itiyuro River clustered (Cluster B) with Aymaran Province localities.

\section{DISCUSSION}

At present there are few cladistic hypotheses available for the freshwater fishes of Argentina. In spite of this, there are some very detailed biogeographical analyses available in which Argentine species have been included. Vari (1988, 1991, 1992) and Vari \& Weitzmann (1990), for example, provided biogeographical analyses of curimatid fishes and other taxa. Schaefer (1991, 1997, Hypoptopomatinae and Otocinclus) also discussed the species present in Argentina and their areas of distribution. Dyer (1998), who studied the phylogeny of South American silversides, provided further evidence for the separation of Odontesthes hatcheri from Patagonia from the remaining species with more northern distributions. Ghedotti (1998) provided a phylogeny of the genus Jenynsia, but stated that the biogeographic patterns derived from his study should be considered only as preliminary.

As a result of the application of objective criteria to evaluating the relationships and similarity among fish localities in Argentina, we obtained five clades, roughly equivalent to the provinces proposed previously (Ringuelet, 1975; Arratia et al., 1983), with some differences in details and some hierarchical changes. The most important differences are the definition of the Aymaran Province and the extension of the Pampean Region. The existence of the former province was foreseen by Menni (2004) and Menni et al. (2005), who mentioned the traits of the fish fauna from north-western Argentina and discussed its ecology. The Pampean Region in the sense of this paper includes a northern section evidently related to tributaries of the Paraná River.

Our results confirm the traditional extension of the Andean Cuyan and Patagonian provinces. The former one is extended to the Atlantic Ocean with the inclusion of the Colorado River.

The resulting classification in which provinces correspond to clades derived from the PAE of $50 \%$ majority consensus is shown in Fig. 4.

\section{Systematic biogeography}

Kingdom AUSTRAL (Kuschel, 1969)

Region ANDEAN (Shannon, 1927) 


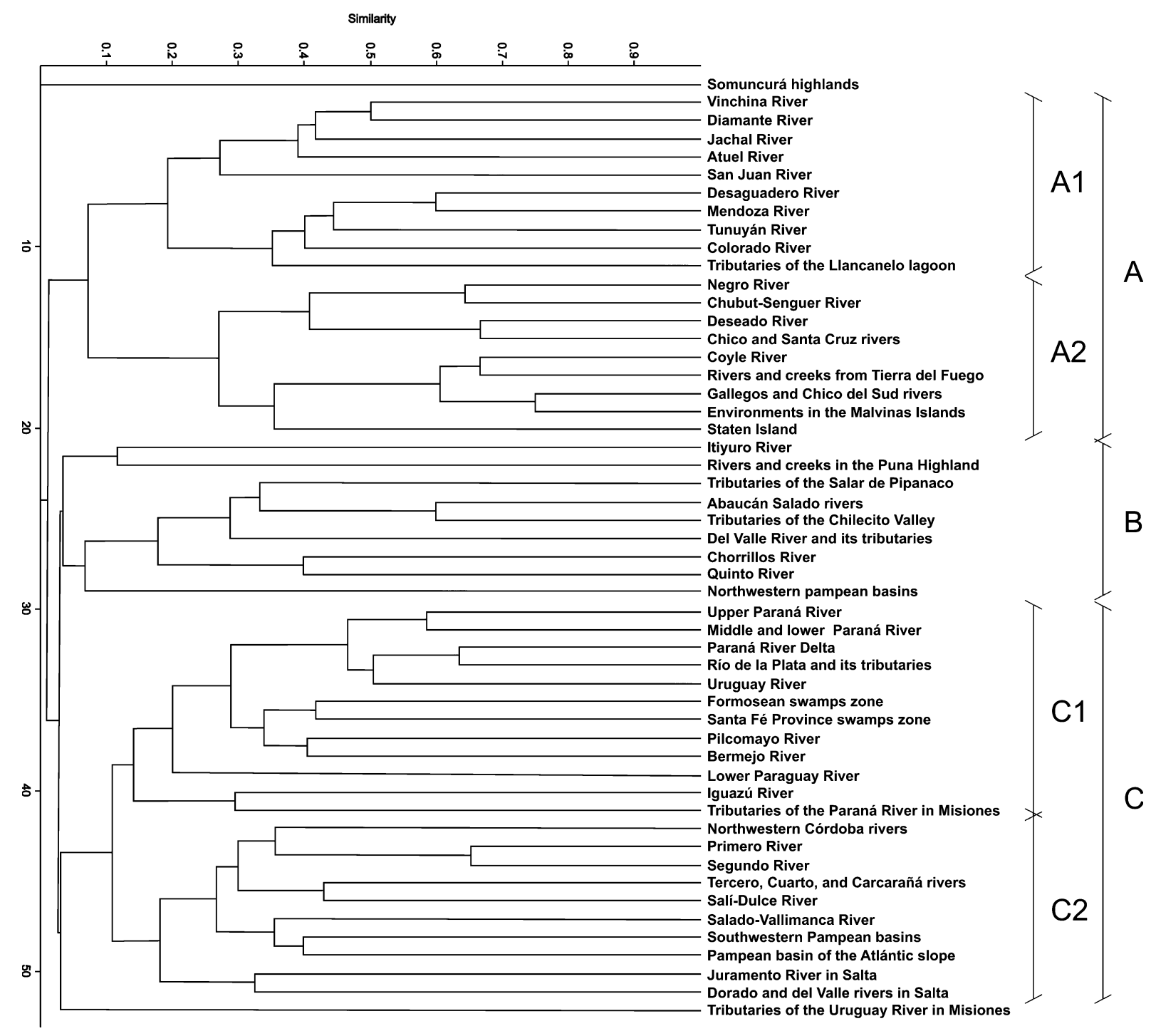

Figure 3 Cluster analysis (UPGMA: unweighted pair-group method using arithmetic averages) resulting from the Jaccard matrix of 52 localities by 440 species. Cophenetic correlation value $=0.90$. A, B and C: main areas. Provinces: C1, Great Rivers; C2, Pampean; B, Aymaran; A1, Andean Cuyan; A2, Patagonian.

\section{Province Andean Cuyan (Clade IV)}

Type locality: Mendoza River $\left(32^{\circ} 49^{\prime} \mathrm{S}, 70^{\circ} 03^{\prime} \mathrm{W}\right.$ to $32^{\circ} 22^{\prime} \mathrm{S}$, $\left.68^{\circ} 15^{\prime} \mathrm{W}\right)$.

Diagnosis: Our results, in agreement with those of Arratia et al. (1983), indicate that the Vinchina Bermejo River, the northernmost limit of Hatcheria macraei and Trichomycterus heterodontus, is the northern end of the Andean Cuyan Province. Hatcheria macraei occurs in all localities of the Andean Cuyan Province, but also occurs in the western part of Patagonia and the lowest Colorado, Negro and Chubut rivers, reaching $47^{\circ} 30^{\prime} \mathrm{S}, 72^{\circ} \mathrm{W}$ (Eigenmann, 1909).

Description: As suggested by Arratia et al. (1983), the PAE gave evidence of two groups of localities within the province. One includes the Vinchina-Bermejo River in La Rioja, the Jachal and San Juan rivers in San Juan Province, and the
Atuel River, the Diamante Pond and the Llancanelo Lake in Mendoza. The other comprises the Desaguadero, Mendoza, Tunuyán and Colorado rivers. The cluster analysis provides a similar topology, but joins the Llancanelo Lake with the second group. In the PAE, the former group appears as a polytomy, and corresponds to the poorest habitats in the province. The second group includes the richest environments. In this area the most common species, besides H. macraei, are Olivaichthys cuyanus, Percichthys trucha and Cheirodon interruptus, the latter with clear Paranensean relationships and a well-known eurytopic species (Menni et al., 1996).

Mac Donagh (1950) noted the presence of the freshwater eel Synbranchus marmoratus in the area, but the first formal report from San Juan is also the most western one in Argentina (Murúa \& Acosta, 1997; Gómez, 2001). 
Figure 4 Ichthyological provinces of Argentina resulting from a parsimony analysis of endemicity (PAE) 50\% majority-rule consensus tree of a matrix of 52 localities by 440 species. Numbers of localities correspond to lists in the text. Areas in white correspond to unresolved localities.

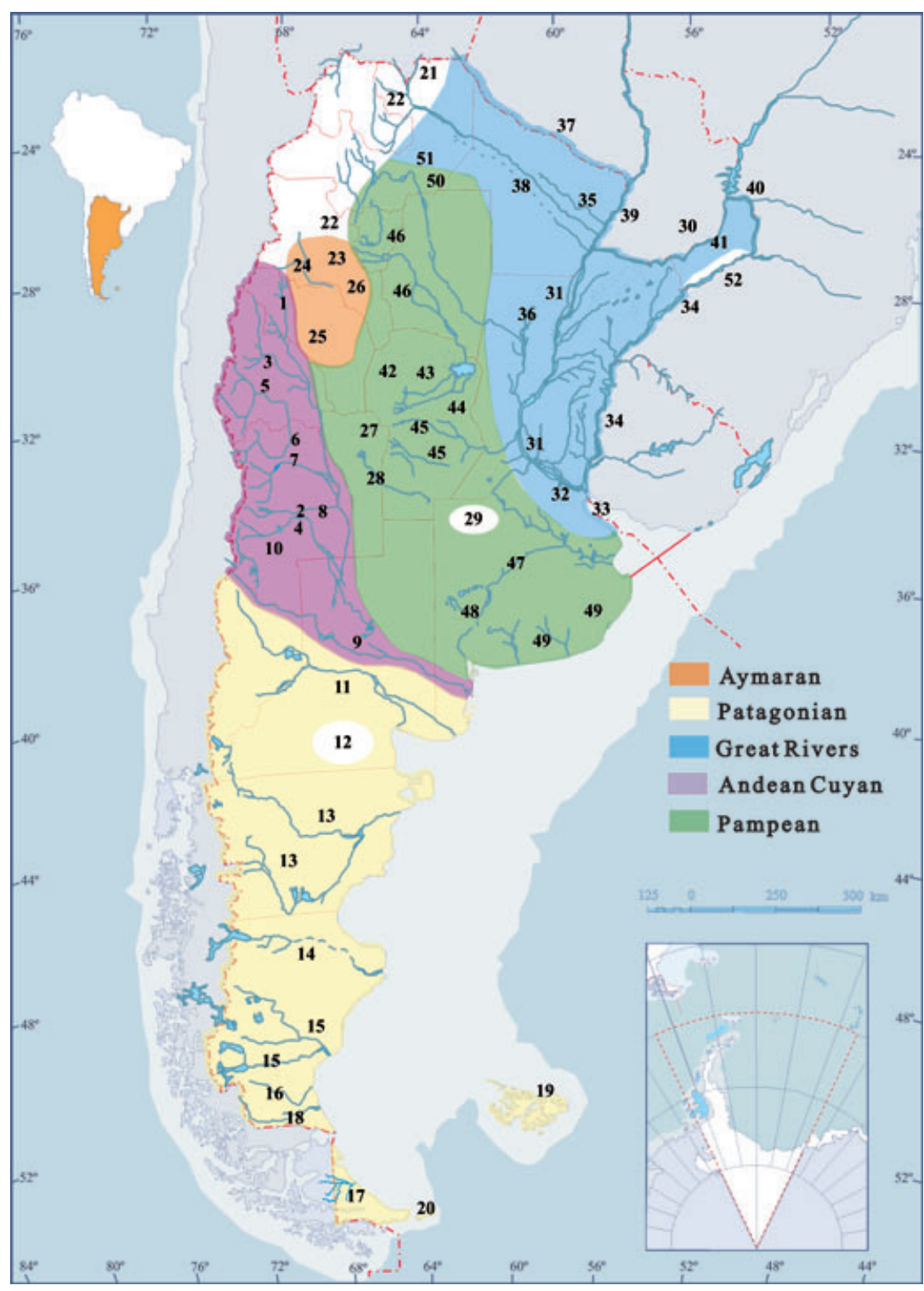

Synbranchus marmoratus is the fish with the widest distribution in South America; therefore, its presence far to the south is not surprising. However, its genetic and caryotypic variation is large (Torres et al., 2005), suggesting that it may include more than one evolutionary lineage.

The Andean Cuyan Province shares with the Aymaran Province Hatcheria macraei, Cheirodon interruptus, Trichomycterus borellii, Jenynsia pygogramma.

The Andean Cuyan Province shares with the Patagonian Province Odontesthes hatcheri, Percichthys trucha, Hatcheria macraei, Olivaichthys viedmensis and Percichthys colhuapiensis.

The Andean Cuyan Province shares several species with the Great Rivers Province, namely Cheirodon interruptus, Trichomycterus borellii, Synbranchus marmoratus, Mugil liza, Oligosarcus jenynsii and Astyanax eigenmanniorum. Differing in the species shared with Patagonia, these species are in general widely distributed through the other provinces. The Andean
Cuyan Province shares with the Pampean Province Astyanax eigenmanniorum, Cheirodon interruptus, Synbranchus marmoratus, Jenynsia pygogramma, Oligosarcus jenynsii, Trichomycterus borellii and Mugil liza.

\section{Province Patagonian (Clade V)}

Type locality: Negro River $\left(39^{\circ} 00^{\prime} \mathrm{S}, 68^{\circ} 00^{\prime} \mathrm{W}\right.$ to $41^{\circ} 02^{\prime} \mathrm{S}$, $\left.62^{\circ} 47^{\prime} \mathrm{W}\right)$.

Diagnosis: This is the best defined province because of the presence of osmeriform fishes of the family Galaxiidae. In all available classifications, it includes southern Argentina and southern Chile (Ringuelet, 1975; Arratia et al., 1983). Here we refer only to the Argentine section. The northern border of the province in Argentina may be conflictive, because the Colorado River, which Almirón et al. (1997) considered a transitional area, appears as a part of the Andean Cuyan Province in our analysis. 
Description: Excluding introduced salmonids, 21 fish species occur in Patagonia (Menni, 2004), considering recent data on Percichthys (López-Arbarello, 2004) and the presence of Corydoras paleatus (possibly introduced) in the northern part (Baigún et al., 2002).

Arratia et al. (1983) considered Patagonia to be divided into two large faunistic regions separated by the Chubut River. Both the PAE and the cluster analyses show a division between a cluster including the Negro, Chubut-Senguer, Deseado, and Chico and Santa Cruz rivers, which are localities with a relatively larger number of species, and another one including the Coyle River, Tierra del Fuego, Gallegos and Chico del Sur rivers, Isla de los Estados and Malvinas Islands which are poorer. The northern cluster includes two species of Galaxias, two species of Aplochiton, the Patagonian silverside Odontesthes hatcheri and Percichtys trucha in all localities considered. There are also Hatcheria macraei in the Negro, Chubut-Senger and Deseado rivers, Olivaichthys viedmensis in the Negro and Chubut-Senguer rivers, O. mesembrinus in the Chubut-Senguer River, and Percichthys colhuapiensis in the Negro and Chubut-Senguer rivers.

In the southern area, Galaxias maculatus occurs in all five localities, and G. platei occurs in four of them. Aplochiton zebra and A. taeniatus occur in the Malvinas Islands, the former also in Tierra del Fuego, and the second also in the Gallegos and Chico del Sur rivers.

Galaxias maculatus, being present in all of them, is the widely distributed species. The Negro and Senguer rivers are much more diverse than the others, having nine species each, with eight species shared. The Patagonian Province shares with the Aymaran Province only Hatcheria macraei. With the Great Rivers and Pampean provinces it only shares Corydoras paleatus, which is a recent observed presence and could be an anthropic introduction.

Discussion: The formal placement of the Andean Cuyan and Patagonian provinces as divisions of a larger group (Andean Region) followed the proposal of Arratia et al. (1983), who considered them, together with the Chilean Province, as part of the Austral Subregion (=Andean sensu Morrone, 1996).

The Colorado River has been considered more closely related to the Paranensean area than to Patagonia, on the basis of several Paranensean species found there relatively recently (Almirón et al., 1997). On the basis that Trichomycterus and Hatcheria macraei are shared with localities in the Clade IV, our analysis suggests a closer relationship of the Colorado River with rivers from middle Western Argentina.

The Andean Cuyan Province shares with the Patagonian Province the family Percichthyidae. At a specific level they share Percichthys trucha and P. colhuapiensis. Percichthys trucha ranges from the system Colorado-Desaguadero (Jachal River, $\left.30^{\circ} 30^{\prime} \mathrm{S}\right)$ to Colhue Huapi Lake, and P. colhuapiensis ranges from the same lake northwards to Tulumayá and Puente de Fierro Lake in Mendoza. Patagonia has an endemic Percichthydae, P. laevis (López-Arbarello, 2004). Note that if there were only a single species of Percichthys (Ruzzante et al., 2006) these differences would not exist. These provinces share the siluriform genus Olivaichthys, with $O$. cuyanus being endemic to the Andean Cuyan Region. Olivaichthys mesembrinus is a Patagonian endemic. Olivaichthys viedmensis is common to both provinces, which also share the Atherinopsidae Odontesthes hatcheri.

Kingdom HOLOTROPICAL (Rapoport, 1968)

Region NEOTROPICAL (Sclater, 1858)

\section{Province Aymaran (Clade III)}

Type locality: Tributaries of the Salar de Pipanaco $\left(28^{\circ} 07^{\prime} \mathrm{S}\right.$, $\left.66^{\circ} 25^{\prime} \mathrm{W}\right)$.

Diagnosis: Clade III includes four localities in middle Western Argentina, in a rather mountainous and dry area. These localities do not have endemic species, but share two species of Trichomycterus, namely T. corduvensis and T. alterus, plus two other less common species.

Description: With the Pampean Province the Aymaran Province shares Trichomycterus barbouri, T. corduvensis, T. alterus, T. borellii, Heptapterus mustelinus, Bryconamericus iheringii, B. rubropictus, Rhamdia quelen, Rineloricaria catamarcensis, Cheirodon interruptus and Jenynsia pygogramma. With the Great Rivers Province it shares Rhamdia quelen, Heptapterus mustelinus, Bryconamericus iheringii, Cheirodon interruptus, Trichomycterus corduvensis, T. alterus, T. barbouri, T. borellii, Rineloricaria catamarcensis and Bryconamericus rubropictus.

\section{Province Great Rivers (Clade I)}

Type locality: Middle Paraná River $\left(27^{\circ} 18^{\prime} \mathrm{S}, 58^{\circ} 36^{\prime} \mathrm{S}\right.$ to $\left.32^{\circ} 07^{\prime} \mathrm{S}, 60^{\circ} 37^{\prime} \mathrm{W}\right)$.

Diagnosis: This province corresponds to the large subtropical region defined by the Argentinean Mesopotamia (the area between the Paraná and Uruguay rivers) and adjacent areas. In the sense used here, the province is more restricted than the Parano Platense Province of either Ringuelet (1975) or Arratia et al. (1983). This difference is a result of the extension of the Pampean Province in our analysis.

Description: There are 394 fish species in the Great Rivers Province, which is by far the richest of Argentina. Ninety-one (23.1\%) are shared with the Pampean Province. In the Great Rivers Province, Salminus brasiliensis, Prochilodus lineatus and Synbranchus marmoratus occur in all localities. The first two species, which are typical migratory species, have a close trophic relationship. Eigenmannia virescens, Roeboides bonariensis, Loricariicthys melanocheilus, Astyanax abramis, Hoplias malabaricus, Pimelodus maculatus, Pimelodella gracilis, Astyanax bimaculatus, A. fasciatus, Odontostilbe pequira, Pimelodus albicans and Pygocentrus nattereri occur in most of the localities. Three localities are much richer than the others, namely Upper Paraná, Middle and Lower Paraná and the Paraná Delta. The Bermejo River, in spite of its not having been much explored, also has a considerable number of species. 
Province Pampean (Clade II)

Type locality: Chascomús Lake $\left(35^{\circ} 36^{\prime} \mathrm{S}, 58^{\circ} 02^{\prime} \mathrm{W}\right)$.

Diagnosis: The 'pampasic fishes' in the sense of Ringuelet (1975) are those of the Salado-Vallimanca River, the Southwestern Pampean basins and the Pampean basins of the Atlantic slope. Fishes of rivers of Córdoba are very similar to those of the Salado area (Menni, 2004). The small fauna from the Pampean basins of the Atlantic slope (Casciotta et al., 1999) is a subset of the Pampean fauna, living in small rivers at the border of the impoverished area limiting with Patagonia. The Sierra de la Ventana highlands at $38^{\circ} \mathrm{S} 62^{\circ} \mathrm{W}$, inhabited by several Paranensean species (Menni et al., 1988), belong to this province. According to our analysis, this province differs from the Pampasic Dominion sensu Ringuelet (1961) in that it includes several localities placed north of the Pampasic Dominion. Astyanax eigenmanniorum, Bryconamericus iheringii, Cheirodon interruptus and Synbranchus marmoratus are the species present in most localities, in agreement with well-known evidence (Menni, 2004). The first three are very eurytopic species (Menni et al., 1996). Note that in north-western Córdoba there are 11 species (including the most abundant of the Pampasic Province), but that the remaining pampasic species are absent. The faunistic similarity between rivers in Córdoba and the Paraná River is well known (Haro \& Bistoni, 1996).

Description: There are 134 species in the Pampean Province. Of these, the following do not occur in the Great Rivers Province: Cheirodon interruptus, Bryconamericus eigenmanni, Trichomycterus tenuis, Jenynsia pygogramma, J. maculata, Astyanax hermosus, Characidium borellii, Crenicichla vittata, Austrolebias nonoiuliensis, A. robustus, Silvinichthys bortayro and Hatcheria macraei.

In the cluster analysis this province is clearly delimited and related to the Great Rivers Province.

\section{CONCLUSIONS}

Using quantitative methods we identified five zoogeographic provinces for Argentine freshwater fish fauna: Andean Cuyan, Patagonian, Aymaran, Great Rivers, and Pampean. These provinces represent the first classification of Argentine ichthyogeographic provinces based on objective methods. Our results confirm the traditional extension of the Andean Cuyan and Patagonian provinces, but the former is extended to the Atlantic Ocean with the inclusion of the Colorado River. The Aymaran Province is defined for the first time, and the Pampean Province is extended to the north.

\section{ACKNOWLEDGEMENTS}

The authors are deeply grateful to G. Ortí, J.V. Crisci and J. J. Morrone for critical reading, to T. Roberts for improving the language, to M. Ebach for helpful comments, and to J. Ponte Gómez for technical support.

\section{REFERENCES}

Almirón, A.E., Gómez, S.E. \& Toresani, N.I. (1992) Peces de agua dulce de la provincia de Buenos Aires, Argentina. Situación ambiental de la provincia de Buenos Aires, CIC, 2, $1-29$.

Almirón, A.E., Azpelicueta, M., Casciotta, J.R. \& López Cazorla, A. (1997) Ichthyogeographic boundaries between the Brazilian and Austral subregions in South America, Argentina. Biogeographica, 73, 23-30.

Amorim, D.S. \& Tozoni, S.H.S. (1994) Phylogenetic and biogeographic analysis of the Anisopodoidea (Diptera, Bibionomorpha), with an area cladogram for intercontinental relationships. Revista brasilera de Entomología, 33, 475-482.

Arratia, G. (1997) Brazilian and Austral freshwater fish faunas of South America. A contrast. Tropical biodiversity and systematics. Proceedings of the International Symposium on Biodiversity \& Systematics in Tropical Ecosystems (ed. by H. Ulrich), pp. 179-187. Zoologisches Forschungsinstitut und Museum Alexander Koenig, Bonn.

Arratia, G., Peñafort, M.B. \& Menu Marque, S. (1983) Peces de la región sureste de los Andes y sus probables relaciones biogeográficas actuales. Deserta, 7, 48-107.

Baigún, C. \& Ferriz, R. (2003) Distribution patterns of native freshwater fishes in Patagonia (Argentina). Organisms Diversity \& Evolution, 3, 151-159.

Baigún, C., López, G., Dománico, A., Ferriz, R., Sverlij, S. \& Delfino Schenke, R. (2002) Presencia de Corydoras paleatus (Jenyns, 1842), una nueva especie brasílica en el Norte de la Patagonia (Río Limay) y consideraciones ecológicas relacionadas con su distribución. Ecología Austral, 12, 41-48.

Banarescu, P. (1995) Zoogeography of freshwaters. Aula Verlag, Wiesbaden.

del Barco, D.M. (1997) Lista de peces de la provincia de Santa Fe. Sistema provincial de áreas naturales protegidas, pp. 97106. Gobierno de la Provincia de Santa Fé, Administración de Parques Nacionales, Asociación Cooperativa de la E.Z.E., Santa Fe.

Berra, T. (2001) Freshwater fish distribution. Academic Press, San Diego, CA.

Bonetto, A.A. (1998) Panorama sinóptico sobre la ictiofauna, la pesca y la piscicultura en los ríos de la cuenca del Plata con especial referencia al Paraná. Revista de Ictiología, 6, 3-15.

Bremer, K. (1988) The limits of amino acid sequence data in angiosperm phylogenetic reconstruction. Evolution, 42, 795803.

Butí, C. (1999) Peces. Biodiversidad de Agua Rica (ed. by E. Lavilla and J.A. González), pp. 147-163. BHP CooperFundación Miguel Lillo, Tucumám.

Butí, C. \& Cancino, F. (2005) Ictiofauna de la cuenca endorreica del río Salí - Dulce, Argentina. Acta Zoológica Lilloana, 49, 9-33.

Cabrera, A.L. \& Willink, A. (1973) Biogeografía de América Latina. Organización de los Estados Americanos, Serie de Biología, Monografía No. 13, Washington. 
Casciotta, J.R., López, H.L., Menni, R.C. \& Miquelarena, A.M. (1989) The first fish fauna from the Salado River (Central Argentina, South America), with additions to the Dulce River and limnological comments. Archive für Hydrobiologie, 115, 603-612.

Casciotta, J.R., Almirón, A.E., Cione, A. \& Azpelicueta, M.M. (1999) Brazilian freshwater fish assemblages from southern pampean area, Argentina. Biogeographica, 75, 67-78.

Casciotta, J.R., Almirón, A.E. \& Bechara, J. (2005) Peces del Iberá. Hábitat y diversidad. UNDP, Fundación Ecos, UNLP, UNNE, La Plata.

Cei, J.M. (1969) La meseta basáltica de Somuncurá, Rio Negro. Herpetofauna endémica y sus peculiares equilibrios biocenóticos. Physis, 28, 257-271.

Crisci, J.V., Cigliano, M.M., Morrone, J.J. \& Roig-Juñent, S. (1991a) A comparative review of cladistic approaches to historical biogeography of southern South America. Australian Systematic Botany, 4, 117-126.

Crisci, J.V., Cigliano, M.M., Morrone, J.J. \& Roig-Juñent, S. (1991b) Historical biogeography of southern South America. Systematic Zoology, 40, 152-171.

Crisci, J.V., Katinas, L. \& Posadas, P. (2000) Introducción a la teoría y practica de la biogeografía histórica. Sociedad Argentina de Botánica, Buenos Aires.

Crisci, J.V., Katinas, L. \& Posadas, P. (2003) Historical biogeography: an introduction. Harvard University Press, Cambridge, MA.

Cussac, V.E., Ortubay, S.G., Iglesias, G., Milano, D., Lattuca, M.E., Barriga, J.P., Battini, M. \& Gross, M. (2004) The distribution of South American galaxiid fishes: the role of biological traits and post-glacial history. Journal of Biogeography, 31, 103-121.

Del Castillo, M. (1986) Nueva aproximación metodológica al estudio de la biogeografía de los peces epicontinentales. Oecologia Aquatica, 8, 71-94.

Dyer, B. (1998) Phylogenetic systematics and historical biogeography of the Neotropical silversides family Atherinopsidae (Teleostei: Atheriniformes). Phylogeny and classification of Neotropical fishes (ed. by R.L. Malabarba, R.E. Reis, R.P. Vari, Z.M. Lucena and C.A.S. Lucena), pp. 519-536. EDIPUCRS, Porto Alegre.

Dyer, B. (2000) Systematic review and biogeography of the freshwater fishes of Chile. Estudios Oceanológicos, 19, 77-98.

Ebach, M.C., Morrone, J.J., Parenti, L.R. \& Viloria, Á.L. (2007) International Code of Area Nomenclature, First Draft. Published by the Systematic and Evolutionary Biogeographical Association, Paris. http://www.sebasite.org

Eigenmann, C.H. (1909) The fresh-water fishes of Patagonia and an examination of the Archiplata-Archelenis theory. Reports of the Princeton Expedition to Patagonia 1896-1899, III (I), Zoology, 3, 225-374.

Felsenstein, J. (1985) Confidence limits on phylogenies: an approach using the bootstrap. Evolution, 39, 783-791.

Fernández, L. \& de Pinna, M.C.C. (2005) Phreatic catfish of the genus Silvinichthys from southern South America (Teleostei, Siluriformes, Trichomycteridae). Copeia, 1, 100-108.
Fernández, L. \& Schaefer, S.A. (2003) Trichomycterus yusca, new species from high elevation of Argentina (Siluriformes: Trichomycteridae). Ichthyological Explorations of Freshwaters, 14, 353-360.

Fernández, L. \& Vari, R.P. (2004) New species of Trichomycterus from mid elevation localities of northwestern Argentina (Siluriformes: Trichomycteridae). Copeia, 4, 876882.

Ferriz, R.A. (1996) Aporte al conocimiento de la ictiofauna de la provincia de San Luis (Argentina). Bioikos, 9-10, 32-34.

Frenguelli, J. (1946) Las grandes unidades físicas del territorio argentino. Geografía de la República Argentina, III (ed. by the Sociedad Argentina de Estudios Geográficos), pp. 5-357, Buenos Aires.

Géry, J. (1969) The freshwater fishes of South America. Biogeography and ecology in South America (ed. by J. Fittkau, J. Illies, H. Klinge, G.H. Schwabe and H. Sioli), pp. 828-848. W. Junk, N.V. Publishers, The Hague.

Géry, J. (1978) Results of the Dr. K. Lüling research in Argentina in 1975. The relationships of the naked characin Gymnocharacinus bergi (Pisces, Cypriniformes, Characoidei) from northern Patagonia. Zoologischer Anzeiger, 205, 403409.

Ghedotti, M.J. (1998) Phylogeny and classification of the Anablepidae (Teleostei: Cyprinodontiformes). Phylogeny and classification of Neotropical fishes (ed. by R.L. Malabarba, R.E. Reis, R.P. Vari, Z.M. Lucena and C.A.S. Lucena), pp. 561-582. EDIPUCRS, Porto Alegre.

Gómez, P.F. (2001) Presencia de Synbranchus marmoratus Bloch (Pisces: Synbranchidae) en la red de riego en el departamento 25 de Mayo, San Juan, Argentina. Multequina, 10, 79-80.

Gómez, S.E. \& Menni, R.C. (2005) Cambio ambiental y desplazamiento de la ictiofauna en el Oeste de la Pampasia (Argentina Central). Biología Acuática, 22, 151-156.

Gómez, S.E., Trenti, P.S. \& Menni, R.C. (2004) New fish populations as evidence of climatic change in former dry areas of the Pampa region (southern South America). Physis $B, 59,43-44$.

Hammer, Ø., Harper, D.A.T. \& Ryan, P.D.. (2001) PAST: Paleontological Statistics Software Package for Education and Data Analysis, Vol. 4. Palaeontologia Electronica, pp. 1-9. http://palaeo-electronica.org/2001_1/past/issue1_01.htm.

Haro, J.G. \& Bistoni, M.A. (1996) Ictiofauna de la provincia de Córdoba. Biodiversidad de la provincia de Córdoba (ed. by E.I. Di Tada and E.H. Bucher), pp. 169-190. Universidad Nacional de Río Cuarto, Río Cuarto.

Haro, J.G., Bistoni, M.A. \& Gutierrez, M. (1998) La fauna de peces del río Carcarañá en la provincia de Córdoba (Argentina). Natura Neotropicalis, 29, 17-23.

Hubalek, Z. (1982) Coefficients of association and similarity, based on binary (presence-absence) data: an evaluation. Biological Review, 57, 669-689.

Hubert, N. \& Renno, J.F. (2006) Historical biogeography of South American freshwater fishes. Journal of Biogeography, 33, 1414-1436. 
Humphries, C.J. \& Parenti, L.R. (1999) Cladistic biogeography, 2nd edn. Oxford Biogeography Series No. 12. Oxford University Press, Oxford.

Kuschel, G. (1969) Biogeography and ecology of South America Coleoptera,. Biogeography and ecology in South America, vol. 2 (ed. by E.J. Fittkau, J. Illies, H. Klinge, G.H. Schwabe and H. Sioli), pp. 709-722. Junk, The Hague.

Lahille, F. (1929) Una hora entre los pejerreyes, 1-59. Facultad de Agronomía y Veterinaria, Universidad de Buenos Aires.

Liotta, J. (2005) Distribución geográfica de los peces de aguas continentales de la República Argentina. Probiota, FCNyM, UNLP, Serie Documentos, 3, 1-701.

López, H.L. \& Miquelarena, A.M. (2005) Biogeografía de los peces continentales de la Argentina. Regionalización biogeográfica en Iberoamérica y tópicos afines (ed. by J. Llorente Bousquets and J.J. Morrone), pp. 509-550. UNAM, México.

López, H.L., Baigún, C., Iwaszkiw, J., Delfino, R. \& Padin, O. (2001) La cuenca del Salado: uso y posibilidades de sus recursos pesqueros. Editorial de la Universidad de La Plata, La Plata.

López, H.L., Morgan, C.C. \& Montenegro, M.J. (2002) Ichthyological ecoregions of Argentina. Probiota, FCNyM, UNLP, Serie Documentos, 1, 1-68. http://www.vidasilvestre. org.ar.

López, H.L., Miquelarena, A.M. \& Menni, R.C. (2003) Lista comentada de los peces continentales de la Argentina. Probiota, FCNyM, UNLP, Serie Técnica y Didáctica, 5, 1-87.

López, H.L., Miquelarena, A.M. \& Ponte Gómez, J. (2005) Biodiversidad y distribución de la ictiofauna mesopotámica. Temas de la biodiversidad del litoral fluvial argentino II (ed. by F.G. Aceñolaza), pp. 311-354. INSUGEO, Miscelánea, Tucumán. http://www.unt.edu.ar/fcsnat/insugeo.

López-Arbarello, A. (2004) Taxonomy of the genus Percichthys (Perciformes: Percichthyidae). Ichthyological Explorations of Freshwaters, 15, 331-350.

Mac Donagh, E.J. (1934) Nuevos conceptos sobre la distribución geográfica de los peces argentinos basados en expediciones del Museo de La Plata. Revista del Museo de La Plata, 34, 21-170.

Mac Donagh, E.J. (1938) Los peces de las aguas termales de Barreto (Córdoba) y la etología de la zona. Revista del Museo de La Plata, Nueva Serie 1, Zoología, 3, 45-87.

Mac Donagh, E.J. (1950) Las razas de percas o truchas criollas (Percichthys) y su valor para la repoblación pesquera. Revista del Museo de La Plata, Zoología, 39, 71-170.

Maddison, D.R. \& Maddison, W.P. (2001) MacClade 4: analysis of phylogeny and character evolution. Version 4.02. Sinauer Associates, Sunderland, MA.

Malabarba, L.R., Reis, R.E., Vari, R.P., Lucena, Z.M.S. \& Lucena, C.A.S. (eds.) (1998) Phylogeny and classification of Neotropical fishes. EDIPUCRS, Porto Alegre.

Matthews, W.J. (1998) Patterns in freshwater fish ecology. Chapman \& Hall, London.

Mazza, G. (1961) Recursos hidráulicos superficiales. Evaluación de los recursos naturales de la Argentina, 4 (ed. by C. Federal de Inversiones), pp. 1-459. CFI, Buenos Aires.
McDowall, R. (1971a) The galaxiid fishes of South America. Zoological Journal of the Linnean Society, 50, 33-73.

McDowall, R. (1971b) Fishes of the family Aplochitonidae. Journal of the Royal Society of New Zealand, 1, 31-52.

Menni, R.C. (2004) Peces y ambientes en la Argentina continental. Monografías del Museo Argentino de Ciencias Naturales, 5, 1-316.

Menni, R.C. \& Gómez, S.G. (1995) On the habitat and isolation of Gymnocharacinus bergi (Osteichthyes: Characidae). Environmental Biology of Fishes, 42, 15-23.

Menni, R.C., López, H.L., Casciotta, J.R. \& Miquelarena, A.M. (1984) Ictiología de áreas serranas de Córdoba y San Luis (Argentina). Biología Acuática, 5, 1-63.

Menni, R.C., López, H.L. \& Arámburu, R.H. (1988) Ictiofauna de Sierra de la Ventana y Chasicó (Provincia de Buenos Aires, Argentina). Zoogeografía y parámetros ambientales. Anales del Museo de Historia Natural de Valparaíso, 19, 7584.

Menni, R.C., Miquelarena, A.M., López, H.L., Casciotta, J.R. \& Protogino, L.C. (1992) Fish fauna and environment of the Pilcomayo-Paraguay basin in Formosa, Argentina. Hydrobiologia, 245, 129-146.

Menni, R.C., Gómez, S.E. \& López Armengol, M.F. (1996) Subtle relationships: freshwater fishes and water chemistry in southern South America. Hydrobiologia, 328, 173-197.

Menni, R.C., Miquelarena, A.M. \& Volpedo, A.C. (2005) Fishes and environment in northwestern Argentina: from lowland to Puna. Hydrobiologia, 544, 33-49.

Miquelarena, A.M. \& Aquino, A.E. (1995) Situación taxonómica y geográfica de Bryconamericus thomasi Fowler, 1940 (Teleostei, Characidae). Revista Brasileira de Biologia, 55, 559-569.

Miquelarena, A.M. \& López, H.L. (1995) Fishes of the lagunas Encadenadas (Province of Buenos Aires, Argentina), a wetland of international importance. Freshwater Forum, 5, 4853.

Miquelarena, A.M. \& Menni, R.C. (1992) Presencia de Oligosarcus jenynsi en el oeste de Córdoba. Neotropica, 38, 154.

Miquelarena, A.M. \& Menni, R.C. (2005) Astyanax tumbayaensis, a new species from northwestern Argentina highlands (Characiformes: Characidae) with a key to the Argentinean species of the genus and comments on their distribution. Revue suisse de Zoologie, 112, 661-676.

Miquelarena, A.M., Menni, R.C., López, H.L. \& Casciotta, J.R. (1990) Ichthyological and limnological observations on the Salí River basin (Tucumán, Argentina). Ichthyological Exploration of Freshwaters, 1, 269-276.

Miquelarena, A.M., Ortubay, S. \& Cussac, V. (2005) Morphology, osteology and reduction in the ontogeny of the scaleless characid Gymnocharacinus bergi. Journal of Applied Ichthyology, 21, 511-519.

Monasterio de Gonzo, G. (2003) Peces de los ríos Bermejo, Juramento y cuencas endorreicas de la provincia de Salta. Museo de Ciencias Naturales y Consejo de Investigación, Universidad Nacional de Salta, Salta. 
Monasterio de Gonzo, G., Barros, S.E., Mamaní, O. \& Mosqueira, M. (2005) Ictiofauna del área noroeste de la cuenca paranoplatense. Natura Neotropicalis, 36, 21-33.

Morrone, J.J. (1996) The biogeographical Andean subregion: a proposal exemplified by arthropod taxa (Arachnida, Crustacea and Hexapoda). Neotropica, 42, 103-114.

Morrone, J.J. (2001) Biogeografía de America Latina y el Caribe. Manuales y Tesis Sea, Sociedad Entomológica Aragonesa, 3, 1-148.

Morrone, J.J. (2002) Biogeographical regions under track and cladistic scrutiny. Journal of Biogeography, 29, 149-152.

Morrone, J.J. (2006) Biogeographic areas and transition zones of Latin America and the Caribbean islands based on panbiogeographic and cladistic analyses of the entomofauna. Annual Review of Entomology, 51, 467-494.

Murguía, M. \& Villaseñor, J.L. (2003) Estimating the effect of the similarity coefficient and the cluster algorithm on biogeographic classifications. Annales Botanici. Fennici, 40, 415-421.

Murúa, F. \& Acosta, J.C. (1997) Synbranchus marmoratus Bloch (Pisces, Synbranchidae). Nuevo registro para la ictiofauna de San Juan (Argentina). Multequina, 6, 103-104.

Ortiz-Jaureguizar, E. \& Cladera, G.A. (2006) Paleoenvironmental evolution of southern South America during the Cenozoic. Journal of Arid Environments, 66, 498-532.

Ortubay, S., Gómez, S.E. \& Cussac, V.E. (1997) Lethal temperatures of a Neotropical fish relict in Patagonia, the scale-less characinid Gymnocharacinus bergi. Environmental Biology of Fishes, 49, 341-350.

Pozzi, A.J. (1945) Sistemática y distribución de los peces de agua dulce de la República Argentina. Gaea, 7, 239-292.

Rapoport, E.H. (1968) Algunos problemas biogeográficos del Nuevo Mundo con especial referencia a la región Neotropical. Biologie de l'Amerique Australe, vol. 4 (ed. by C. Delamare Deboutteville and E.H. Rapoport), pp. 54-110. CNRS and CNICT, Paris.

Ringuelet, R.A. (1961) Rasgos fundamentales de la zoogeografía de la Argentina. Physis, 22, 151-170.

Ringuelet, R.A. (1975) Zoogeografía y ecología de los peces de aguas continentales de la Argentina y consideraciones sobre las áreas ictiológicas de América del Sur. Ecosur, 2, $1-122$.

Ringuelet, R.A., Arámburu, R.H. \& Alonso de Arámburu, A. (1967) Los peces argentinos de agua dulce. Comisión de Investigaciones Científicas de la Provincia de Buenos Aires, La Plata.

Roig, V.G. \& Cei, J.M. (1961) Relaciones biogeográficas entre Misiones y el sistema de la Serra Geral. Boletín de Estudios Geográficos, 8, 35-85.

Rosen, B.R. (1988) From fossils to Earth history: applied historical biogeography. Analytical biogeography: an integrated approach to the study of animal and plant distribution (ed. by A.A. Myers and P.S. Giller), pp. 437-481. Chapman \& Hall, London.

Ruzzante, D.E., Walde, S.J., Cussac, V.E., Dalebout, M., Seibert, J., Ortubay, S. \& Habit, E. (2006) Phylogeography of the Percichthyidae (Pisces) in Patagonia: roles of orogeny, glaciation and vulcanism. Molecular Ecology, 15, 2949-2968.

Schaefer, S.A. (1991) Phylogenetics analysis of the loricariid subfamily Hypoptopomatinae (Pisces: Siluroidei: Loricariidae), with comments on generic diagnosis and geographic distribution. Zoological Journal of the Linnean Society, 102, $1-41$.

Schaefer, S.A. (1997) The Neotropical cascudinhos: systematics and biogeography of the Otocinclus catfish (Siluriformes: Loricariidae). Proceedings of the Academy of Natural Sciences of Philadelphia, 148, 1-120.

Sclater, P.L. (1858) On the general geographical distribution of the members of the class Aves. Journal of the Linnaean Society of Zoology, 2, 130-145.

Shannon, R.C. (1927) Contribución a los estudios de las zonas biológicas de la República Argentina. Revista de la Sociedad Entomológica Argentina, 4, 1-14.

Sivasundar, A., Bermingham, E. \& Orti, G. (2001) Population structure and biogeography of migratory freshwater fishes (Prochilodus: Characiformes) in major South American rivers. Molecular Ecology, 10, 407-417.

Sokal, R.R. \& Rohlf, F.J. (1962) The comparison of dendrograms by objectives methods. Taxon, 11, 33-40.

Sverlij, S.V., Delfino Schenke, R.L., López, H.L. \& Espinach Ros, A. (1998) Peces del río Uruguay. Guía ilustrada de las especies más comunes del río Uruguay y el embalse de Salto Grande. Comisión Administradora del Río Uruguay, Paysandú.

Swofford, D.L. (1998) PAUP*. Phylogenetic analysis using parsimony (* and other methods), Version 4. Sinauer Associates, Sunderland, MA.

Tonni, E.P. \& Cione, A.C. (1997) Did the Argentine Pampas ecosystem exist in the Pleistocene? Current Research on the Pleistocene, 14, 131-133.

Torres, R.A., Roper, J.J., Foresti, F. \& Oliveira, C. (2005) Surprising genomic diversity in the Neotropical fish Synbranchus marmoratus (Teleostei: Synbranchidae): how many species? Neotropical Ichthyology, 3, 277-284.

Vari, R.P. (1988) The Curimatidae, a lowland Neotropical fish family (Pisces, Characiformes), distribution, endemism, and phylogenetic biogeography. Proceeding of the workshop on Neotropical distribution patterns (ed. by W.R. Heyer and P.E. Vanzolini), pp. 343-377. Academia Brasileira de Ciencias, Río de Janeiro.

Vari, R.P. (1991) Systematics of the Neotropical characiform genus Steindachnerina Fowler (Pisces: Ostariophysi). Smithsonian Contributions to Zoology, 507, 1-118.

Vari, R.P. (1992) Systematics of the Neotropical characiform genus Cyphocharax Fowler (Pisces: Ostariophysi). Smithsonian Contributions to Zoology, 529, 1-137.

Vari, R.P. \& Weitzmann, S.H. (1990) A review of the phylogenetic biogeography of the freshwater of South America. Vertebrates in the tropics (ed. by G. Peters and R. Hutterer), pp. 381-393. Museum Alexander Koenig, Bonn. 
Vucetich, M.G. \& Verzi, D.H. (1999) Change in diversity and distribution of meridional Caviomorphs (Rodentia) during the Late Cenozoic. Quaternary of South America and Antarctic Peninsula, 12, 185-199.

\section{SUPPLEMENTARY MATERIAL}

The following supplementary material is available for this article:

Appendix S1 Original data matrix of 52 Argentinean localities by 440 freshwater fish species.
This material is available as part of the online article from: http://www.blackwell-synergy.com/doi/abs/10.1111/j. 1365.2699.2008.01904.x (This link will take you to the article abstract).

Please note: Blackwell Publishing is not responsible for the content or functionality of any supplementary materials supplied by the authors. Any queries (other than missing material) should be directed to the corresponding author for the article.

\section{BIOSKETCHES}

Hugo L. López is a researcher at the Council of Scientific Research of Buenos Aires Province, Argentina. His main interests are the systematics, biodiversity, biogeography and conservation of the continental ichthyofauna of Argentina.

Roberto C. Menni is a researcher at the Consejo Nacional de Investigaciones Científicas (Argentina). His main interests are the community ecology and patterns of distribution of both marine and freshwater fishes.

Mariano Donato is a CONICET (Consejo Nacional de Investigaciones Científicas y Técnicas, Argentina) researcher at the La Plata Museum, Argentina. His interests include Chironomidae (Diptera) systematics and biogeography, the biogeography of southern South America, and cladistic methods.

Amalia M. Miquelarena is a CONICET (Consejo Nacional de Investigaciones Científicas y Técnicas, Argentina) researcher at the La Plata Museum, and a professor at the La Plata University, Argentina. She works on the systematics, anatomy, biodiversity and distribution of freshwater fishes from Argentina.

Editor: Malte Ebach 